DOI: https://doi.org/10.31933/jemsi.v3i1 Received: 22 Juni 2021, Revised: 15 Juli 2021, Publish: 4 September 2021

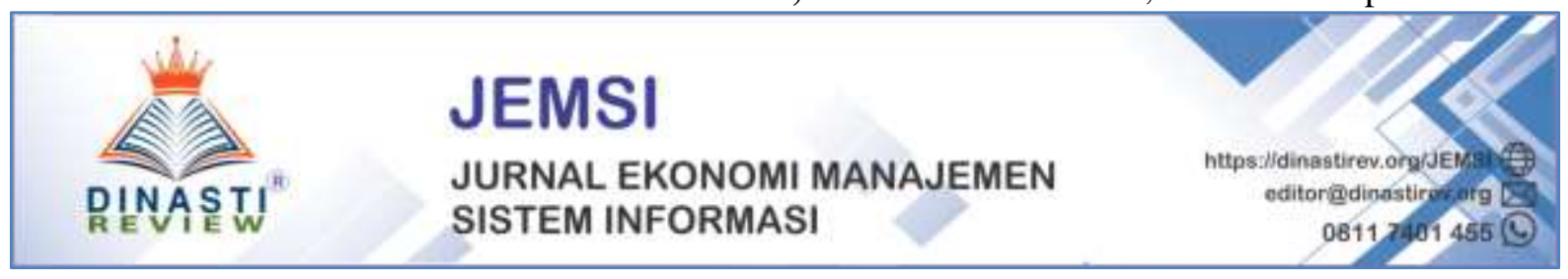

\title{
FAKTOR YANG MEMPENGARUHI MANAJEMEN PENDIDIKAN ISLAM: SISTEM PENDIDIKAN, PENGELOLAAN PENDIDIKAN, DAN TENAGA PENDIDIKAN
}

\author{
Subronto Subronto ${ }^{1}$, Hapzi Ali ${ }^{2}$, Kemas Imron Rosadi ${ }^{3}$ \\ 1) Manajemen Pendidikan Islam, UIN Sultan Thaha Jambi, subronto.zidan@ gmail.com \\ 2) Manajemen Pendidikan Islam, UIN Sultan Thaha Jambi dan UBHARA Jakarta Raya, \\ hapzi@dsn.ubharajaya.ac.id \\ 3) Manajemen Pendidikan Islam, UIN Sultan Thaha Jambi, \\ kemasimronrosadi@uinjambi.ac.id
}

Corresponding Author: Subronto ${ }^{1}$

Abstract: Riset terdahulu atau riset yang relevan sangat penting dalam suatu riset atau artikel ilmiah. Riset terdahulu atau riset yang relevan berfungsi untuk memperkuat teori dan penomena hubungan atau pengaruh antar variable. Artikel ini mereview Manajemen Pendidikan Islam mempengaruhi Sistem Pendidikan, Pengelolaan Pendidikan dan Tenaga Kependidikan, Hasil artikel literature review ini adalah: 1) Bagaimana Sistem Pendidikan berpengaruh terhadap Manajemen Pendidikan Islam; 2) Pengelolaan Pendidikan berpengaruh terhadap Manajemen Pendidikan Islam; dan 3) Tenaga Kependidikan berpengaruh terhadap Manajemen Pendidikan Islam

Keyword: Manajemen Pendidikan Islam, Sistem Pendidikan, Pengelolaan Pendidikan dan Tenaga Kependidikan

\section{INTRODUCTION}

\section{Latar Belakang Masalah.}

Setiap mahasiswa baik Strata 1, Strata 2 dan Strata 3, di wajibkan untuk melakukan riset dalam bentuk skripsi, tesis dan disertasi. Begitu juga bagi dosen, peneliti dan tenaga fungsional lainya aktif melakukan riset dan membuat artikel ilmiah untuk di publikasi pada jurnal-jurnal ilmiah.

Karya ilmiah merupakan salah satu syarat bagi mahasiswa untuk menyelesaikan studi pada sebagian besar Perguruan Tinggi di Indonesia. Ketentuan ini berlaku hampir untuk level jenjang pendidikan yaitu strata satu (S1) berupa Skripsi, untuk mahasiswa strata dua (S2) berupa Tesis, dan untuk mahasiswa strata tiga (S3) berupa Disertasi.

Berdasarkan pengalaman empirik banyak mahasiswa dan author yang kesulitan dalam mencari artikel pendukung untuk karya ilmiahnya sebagai penelitian terdahulu atau sebagai 
penelitian yang relevan. Artikel yang relevan di perlukan untuk memperkuat teoti yang di teliti, untuk melihat hubungan antar variable dan membangun hipotesis, juga sangat diperlukan pada pembahasan hasil penelitian.

Artikel ini mereview Faktor-faktor mempengaruhi Manajemen Pendidikan Islam: Sistem Pendidikan, Pengelolaan Pendidikan, dan Tenaga Pendidik.

\section{Rumusan Masalah.}

Berdasarkan latar belakang akan di rumuskan masalah yang akan di bahas pada artikel literature review agar lebih focus pada kajian pustaka dan hasil serta pembahasan nanti, yaitu:

1. Apakah Sistem Pendidikan memiliki hubungan dan berpengaruh terhadap Manajemen Pendidikan Islam

2. Apakah Pengelolaan Pendidikan memiliki hubungan dan berpengaruh terhadap Manajemen Pendidikan Islam

3. Apakah Tenaga Kependidikan memiliki hubungan dan berpengaruh terhadap Manajemen Pendidikan Islam

\section{KAJIAN TEORI}

\section{Manajemen Pendidikan Islam}

Pendidikan yang bermutu dapat terwujud dengan melibatkan seluruh komponen pendidikan, karena pendidikan merupakan tanggung jawab bersama. Pemahaman dan komitmen yang sama antara guru, orangtua dan masyarakat dalam pendidikan sangat diperlukan untuk meningkatkan mutu pendidikan serta harus disederhanakan dalam bentuk pola berpikir kesisteman (Sistematic Thinking). Social Support merupakan bentuk wujud kepedulian dari lingkungan sekitar baik berupa dukungan dalam peningkatan mutu dan kualitas pendidikan yang komplek (Iryani et al., 2021).

Pengertian berpikir sistemik dalam konteks tulisan ini harus ditulis di antara dua tanda petik. Alasannya adalah pengertian ini tidak didasarkan pada pengetahuan refrensial dan kebenaran koherensi, melainkan didasarkan pada hasil berpikir sistemik itu sendiri yang bersifat logis-personal (gagasan) yang ditawarkan kepada siapapun yang sempat mendengar pidato dan/atau membaca tulisan ini sebagai proposisi untuk diuji logika dan hipotesis untuk diuji fakta.Secara visual perbandingan cara berpikir taksonomik dan sistemik (Asrifan, 2021).

\section{Aplikasi Hasil Berpikir Sistemik}

Pengambilan keputusan, sistemik, proses berpikir, asimilasi, akomodasi. Pengembangan proses berpikir mahasiswa dalam Sebuah pembelajaran telah menggeser kegiatan pembelajaran yang hanya berfokus dalam mencari solusi masalah ke penciptaan suatu sistem yang dapat digeneralisasikan dan dapat diimplementasikan kembali. Pengembangan proses berpikir mahasiswa tentang sekumpulan data mempunyai peran yang sangat penting dalam pengajaran dan pembelajaran tentang pengantar statistika, terutama penekanan pada masalah problem posing, pembuatan data dan mengintepretasikan, menguantifikasi informasi kualitatif, dan representasi serta mengomunikasikan hasil (Djunaidi, 2020). 


\section{Sistem Pendidikan}

Manajemen sumberdaya manusia (SDM). Setiap organisasi dituntut untuk memiliki SDM yang berkualitas dan memiliki daya saing yang tinggi sehingga mampu menjadi energi bagi organisasi untuk bersaing dengan kompetitornya di tengah arus perubahan yang semakin dinamis. Tuntutan SDM yang berkualitas dan berdaya saing bukan hanya merupakan tuntutan organisasi dan kompetitornya, namun juga tuntutan pelanggan organisasi itu sendiri, terutama pelanggan eksternalnya. Saat ini pelanggan eksternal organisasi dihadapkan pada banyaknya alternatif untuk mengambil keputusan sehingga ia memiliki banyak pilihan dalam menentukan produk dan jasa organisasi mana yang ia konsumsi (Priansa, 2014). .

Pengembangan SDM Indonesia lebih condong kepada manajemen SDM ala Jepang, karena masyarakat Indonesia juga mempunyai kultur menghargai keluarga dan kebersamaan. Saat ini belum ada studi yang komprehensif tentang manajemen SDM pendidikan berangkat dari local culture Indonesia. Juga belum ada studi yang memadahi tentang manajemen SDM dalam konteks pendidikan Islam, dimana studi SDM dikembangkan dari nilai-nilai Islam (Tinggi et al., n.d.).

Perencanaan dalam arti yang sederhana dapat dijelaskan sebagai suatu proses mempersiapkan hal-hal yang akan dikerjakan pada waktu yang akan datang untuk mencapai suatu tujuan yang telah ditetapkan terlebih dahulu (Enoch, 1995:1). Hal senada dengan penjelasan ini, Hamalik (1991:22) menjelaskan perencanaan adalah proses manajerial dalam menentukan apa yang akan dikerjakan dan bagaimana mengerjakannya, dan didalamnya digariskan tujuan yang akan dicapai dan dikembangkan pula program kerja untuk mencapai tujuan itu (Ananda \& Amiruddin, 2019).

Perencanaan merupakan suatu proyeksi tentang apa yang harus dilaksanakan guna mencapai sasaran dan tujuan yang telah ditetapkan (Kaufman 1972; Hadikumoro 1980). Sebagai suatu proyeksi, perencanaan memiliki unsur kegiatan mengidentifikasi, menginventarisasi dan menyeleksi kebutuhan berdasarkan skala prioritas, mengadakan spesifikasi yang lebih rinci mengenai hasil yang akan dicapai, mengidentifikasi persyaratan atau kriteria untuk memenuhi setiap kebutuhan, serta mengidentifikasi kemungkinan alternatif, strategi, dan sasaran bagi pelaksanaannya (Somantri, 2014).

\section{Pengelolaan Pendidikan}

Konsep epistemologi pendidikan Islam pada akhir-akhir ini masih tetap menjadi wacana intelektual pendidikan Islam yang sedang dicari formulasi idealnya. Kajian tentang modernisasi dan pengembangan pendidikan Islam, akan banyak dijumpai berbagai hambatan epistemologi dan teologis. Di sisi lain adanya tarik menarik yang mengakibatkan kekaburan antara aspek filosofis yang diperlukan dan aspek teologis yang tampaknya agak sulit dilepaskannya dalam pendidikan Islam. Perbedaan yang sangat tipis antara aspek filosofis dan teologis ini akan tampak ketika masuk dalam belantara kajian ilmu agama Islam itu sendiri. Penulisan ini lebih mendekatkan kepada epistemologis filsafat Arab yang telah dipetakan oleh al-Jabiri. Untuk memecahkan kebekuan epistemologi dalam ilmu-ilmu keislaman ini, perlu diambil langkah pembebasan urusan epistemologi dan dominasi teologis. Cara berpikir 
yang bertolak dari hal-hal yang transendental (nash) perlu dibalik seratus delapan puluh derajat kepada cara berpikir yang berpangkal pada hal-hal yang empiric (Tabrani, 2013)

Suatu organisasi pasti memiliki cita-cita yang ingin diraih. Tujuan-tersebut diraih dengan mendayagunakan sumber daya yang ada. Dan di antara sumber daya yang paling penting adalah SDM (sumber daya manusia). Karena untuk menjadikan pendidikan berkualitas, terutama dalam hal ini adalah lembaga pendidikan, maka sumber daya manusianya harus berkualitas juga (Priyatna, 2017).

Sumber daya manusia merupakan unsur yang sangat vital dalam setiap organisasi, karena faktor sumber daya manusia sangat dominan dalam proses kerja organisasi, maka untuk mencapai tujuan organisasi perlu diadakan pengembangan sumber daya manusia yang dilakukan untuk meningkatkan kinerja, keterampilan, prilaku serta pengetahuan pegawai. Disamping itu, perubahan yang terjadi seiring modernisasi baik dalam lingkup organisasi maupun di luar organisasi menuntut untuk pengembangan sumber daya manusia, sehingga sebagai investasi dalam organisasi, sdm memegang peranan penting terhadap pertumbuhan suatu bangsa. Untuk itu sebagai sumber daya utama organisasi, perhatian penuh terhadap sumber daya manusia suatu keniscayaan, karena kondisi lingkungan yang dinamis, penempatan pegawai, tidak selalu menyebabkan keberhasilan, kondisi lingkungan yang cenderung berubah mengharuskan organisasi secara kontinyu melakukan penyesuaian dan pengembangan sumber daya manusia sesuai kebutuhan organisasi (Priyatna, 2017).

\section{Tenaga Pendidik}

Untuk memberikan wawasan pandangan pendidikan kepada pembaca, pengamat, akademisi, dan praktisi pendidikan untuk memahami bagaimana perbandingan-perbandingan dari berbagi sudut dan dengan kesadaran masyarakat akan pentingnya pendidikan, diharapkan kontrol pendidikan di Indonesia dapat menjadi lebih baik dan terus berkembang serta meningkat. Sehingga memunculkan pertanyaan penelitian bagaimana dalam mengembangkan manajemen mutu pendidikan di era otonomi daerah dan otonomi pendidikan melalui penerapan prinsip-prinsip manajemen dengan paradigma pendidikan. Hasil penelitian ini yakni Peningkatan mutu melaui optimalisasi Fungsi dan Tujuan Standarisasi adalah (1) Standar Nasional Pendidikan berfungsi sebagai dasar dalam perencanaan, pelaksanaan, dan pengawasan pendidikan dalam rangka mewujudkan pendidikan nasional yang bermutu, (2) Standar Nasional Pendidikan bertujuan menjamin mutu pendidikan nasional dalam rangka mencerdaskan kehidupan bangsa dan membentuk watak serta peradaban bangsa yang bermartabat, (3) Standar Nasional Pendidikan disempurnakan secara terencana, terarah, dan berkelanjutan sesuai dengan tuntutan perubahan kehidupan lokal, nasional, dan global. dampak hasil pengembangan pendidikan dasar terhadap otonomi daerah (Umam, 2020).

Memang membangun sebuah sekolah sesuai dengan kontruksinya memang mudah. Tapi membentuk karakter peserta didik tidak semudah membentuk sebuah bangunan lembaga pendidikan. Salah satu hal penting yang menentukan sistem pendidikan adalah mengontrol sistem pendidikan dengan melakukan evaluasi kurikulum. Hamalik menegaskan bahwa ada beberapa faktor yang harus diperhatikan oleh lembaga 
pendidikan dalam pelaksanaan kurikulum, faktor-faktor tersebut sangat mempengaruhi implementasi kurikulum di lapangan (Mushafak, 2015)

Quality merupakan ide yang belum dapat didefinisikan secara final. Ada beberapa makna yang satu dengan yang lain saling melengkapi. Quality dalam dunia pendidikan secara filosofi dimaknai setidaknya dalam dua makna yakni sebagai continous improvement dan force field analysis yang digunakan untuk perbaikan kualitas dalam tindakan manajemen untuk mencapai kebutuhan dan harapan para pelanggan. Ia selalu diarahkan pada "mengutamakan peserta didik" atau program perbaikan sekolah yang berkelanjutan. Karakter yang diinginkan dalam quality bagi lembaga pendidikan [Islam] yaitu: (1) fokus pada pelanggan baik internal maupun eksternal; (2). Adanya keterlibatan total; (3) Adanya ukuran baku mutu lulusan; (4) Adanya komitmen; dan (5) adanya perbaikan yang berkelanjutan (Umam, 2020).

\section{METODE PENELITIAN}

Metode penulisan artikel ilmiah ini adalah dengan metode kualitatif dan studi literature atau Library Research. Mengkaji Buku-buku literature sesuai dengan teori yang di bahas khusunya di lingkup Manajemen Pendidikan Islam Disamping itu menganalisis artikelartikel ilmiah yang bereputasi dan juga artikel ilmiah dari jurnal yang belum bereputasi. Semua artikel ilmiah yang di citasi bersumber dari Mendeley dan Scholar Google.

Dalam penelitian kualitatif, kajian pustaka harus digunakan secara konsisten dengan asumsi-asumsi metodologis. Artinya harus digunakan secara induktif sehingga tidak mengarahkan pertanyaan-pertanyaan yang diajukan oleh peneliti. Salah satu alasan utama untuk melakukan penelitian kualitatif yaitu bahwa penelitian tersebut bersifat eksploratif, (Ali \& Limakrisna, 2013).

Selanjutnya dibahas secara mendalam pada bagian yang berjudul" Pustaka Terkait" (Related Literature) atau Kajian pustaka( "Review of Literature"), sebagai dasar perumusan hipotesis dan selanjutnya akan menjadi dasar untuk melakukan perbandingan dengan hasil atau temuan-temuan yang terungkap dalam penelitian, (Ali \& Limakrisna, 2013).

\section{HASIL DAN PEMBAHASAN}

\section{Pengaruh atau hubungan Sistem Pendidikan terhadap Manajemen Pendidikan Islam}

Seorang perencana jika dia mampu berpikir sistemik maka dalam merencanakan sesuatu dia senantiasa melakukan : (1) Identifikasi, mencari tahu apa unsur saja yang berkaitan dan bisa mendukung pencapaian tujuan; (2) Elaborasi, mencoba memahami dengan baik semua unsur yang teridentifikasi; (3)Klasifikasi unsur-unsur berdasarkan persamaan karakteristik; (4) gradasi, mengurut berdasarkan prioritas (tingkat kepentingan dan kemendesakannya); (5) porsi, memberi bobot berdasarkan gradasinya; (6) aksi, melaksanakan rencana yang telah dibuat (Priansa, 2014)

Seorang majikan jika dia mampu berpikir sistemik maka senantiasa menyeimbangakan antara: (1) Rezeki dan Resiko; (2) Tuntutan dan Tuntunan; (3) Tantangan dan Tentengan. Jika tidak dia akan bangkrut terlilit utang atau bubar karena didemo oleh buruhnya (Ananda \& Amiruddin, 2019) 
Perencanaan adalah proses manajerial dalam menentukan apa yang akan dikerjakan dan bagaimana mengerjakannya, dan berpengaruh terhadap berpikir sistemik yang dikemukan di atas sepintas nampak sederhana, namun ketika kita akan mengplikasikannya dalam kehidupan keseharian kita mungkin kita mengalami kesulitan karena terbiasa berpikir taksonomik yang terbiasa memandang sesuatu dari sudut pandang monodimensional (Somantri, 2014)

Sistem perencanaan pembelajaran dalam pendidikan merupakan proses dalam rangka mempengaruhi peserta didik supaya mampu menyesuaikan diri sebaik mungkin dengan lingkungannya dan yang akan menimbulkan perubahan pada dirinya yang memungkinkan ia berfungsi sesuai kompetensinya dalam kehidupan masyarakat.Dilihat dari sudut pengertian dan defenisi, dengan demikian pendidikan itu ialah usaha sadar yang dilakukan oleh keluarga, masyarakat dan pemerintah melalui bimbingan, pengajaran dan atau latihan yang berlangsung di sekolah dan luar sekolah. Usaha sadar tersebut dilakukan dalam bentuk pembelajaran di mana ada pendidik yang melayani para siswanya dalam melakukan kegiatan belajar, dan pendidik menilai atau mengukur tingkat keberhasilan belajar siswa tersebut dengan prosedur yang ditentukan (Dolong, 2016).

\section{Pengaruh atau hubungan Pengelolaan Pendidikan terhadap Manajemen Pendidikan Islam}

Modernisasi dan pengembangan pendidikan Islam, akan banyak dijumpai berbagai hambatan epistemologi dan teologis yang tampaknya agak sulit dilepaskannya dalam pendidikan Islam. Perbedaan yang sangat tipis antara aspek filosofis dan teologis ini akan tampak ketika masuk dalam belantara kajian ilmu agama Islam itu sendiri (Djunaidi, 2020).

Pengembangan pengajaran secara sistematik yang menggunakan secara khusus teoriteori pembelajaran dan pengajaran untuk menjamin kualitas pembelajaran. Dalam perencanaan ini kebutuhan dianalisis dari proses belajar dengan alur yang sistematik untuk mencapai tujuan pembelajaran. Termasuk di dalamnya melakukan evaluasi terhadap materi pelajaran dan aktivitas-aktivitas pengajaran. ide pengajaran yang dikembangkan dengan memberikan hubungan pengajaran dari waktu ke waktu dalam suatu proses yang dikerjakan, di mana perencana (guru) mengecek secara cermat bahwa semua kegiatan telah sesuai dengan tuntutan sains dan dilaksanakan secara sistematik (Dolong, 2016).

Pada penyelenggaraan pendidikan Islam diperlukan usaha yang lebih, sebab tantangan zaman yang semakin kompleks serta tekanan untuk meningkatkan kepercayaan masyarakat perlu dilakukan segera. Pendekatan sistem atau berpikir kesisteman adalah salah satu solusi mendasar yang harus dipahami dan diterapkan oleh setiap manajer lembaga pendidikan Islam bertujuan mengungkap faktor yang mempengaruhi model sistem pendidikan Islam (Fahrurazi \& Rosadi, 2021)

\section{Pengaruh atau hubungan Tenaga Kependidikan terhadap Manajemen Pendidikan Islam}

Berdasarkan pada pendapat para ahli, maka indikator habits of mind dari pada penelitian ini adalah sebagai berikut: Bertahan atau pantang menyerah; mengatur kata hati; 
mendengarkan pendapat orang lain dengan rasa empati; berfikir luwes; berfikir metakognitif; berusaha bekerja teliti dan tepat; bertanya dan mengajukan masalah secara efektif; memanfaatkan pengalaman lama untuk membentuk pengetahuan baru; berfikir dan berkomunikasi secara jelas dan tepat; memanfaatkan indera dalam mengumpulkan dan mengolah data; mencipta, berkhayal dan berinovasi; bersemangat dan merespon; berani bertanggung jawab dan menghadapi resiko; humoris; berfikir saling bergantungan; belajar berkelanjutan (Hanifah et al., 2018).

Salah satu dari terabainya self control dimana yang mulanya dianggap sebagai masalah sederhana yang sering dilakukan pelajar yaitu membolos. Seperti halnya di Amerika Serikat, setiap hari, ratusan dari ribuan remaja absen dari sekolah tanpa ijin dan alasan yang tidak jelas. Di negara ini, membolos adalah masalah yang mulai meresahkan. Karena menurut beberapa penelitian, perilaku membolos sangat dipercaya sebagai prediktor munculnya kenakalan para remaja. Jika seorang siswa memiliki self control yang rendah atas dirinya, maka siswa tersebut tidak akan dapat mengelola dirinya sendiri, termasuk mengelola kecerdasannya (Ahmad, 2017).

Mengembangkan tingkat pemikiran yang tinggi, keterampilan komunikasi, meningkatkan minat, percaya diri, kesadaran bersosial, dan toleransi terhadap perbedaan individu ditujukan untuk menyiapkan dengan berbagai keterampilan dan kecakapan, seperti berpikir kreatif, inovatif, kritis, pemecahan masalah, komunikasi, kolaborasi dan kerjasama, ICT Literacy, dan kepemimpinan. diharapkan dapat memberi ruang kepada manusia untuk menemukan dan membangun konsep sendiri. Hal ini sejalan dengan pembelajaran konstruktivisme, pemahaman diperoleh karena interaksi antara permasalahan dengan lingkungan belajar, siswa menemukan sendiri pemecahan masalah yang dihadapi, sehingga akan lebih terstimulasi. (Susanti et al., 2015)

\section{Conceptual Framework}

Berdasarkan rumusan masalah penulisan artikel ini dan kajian studi literature review baik dari buku dan artikel yang relevan, maka di perolah Kerangka artikel ini seperti di bawah ini.

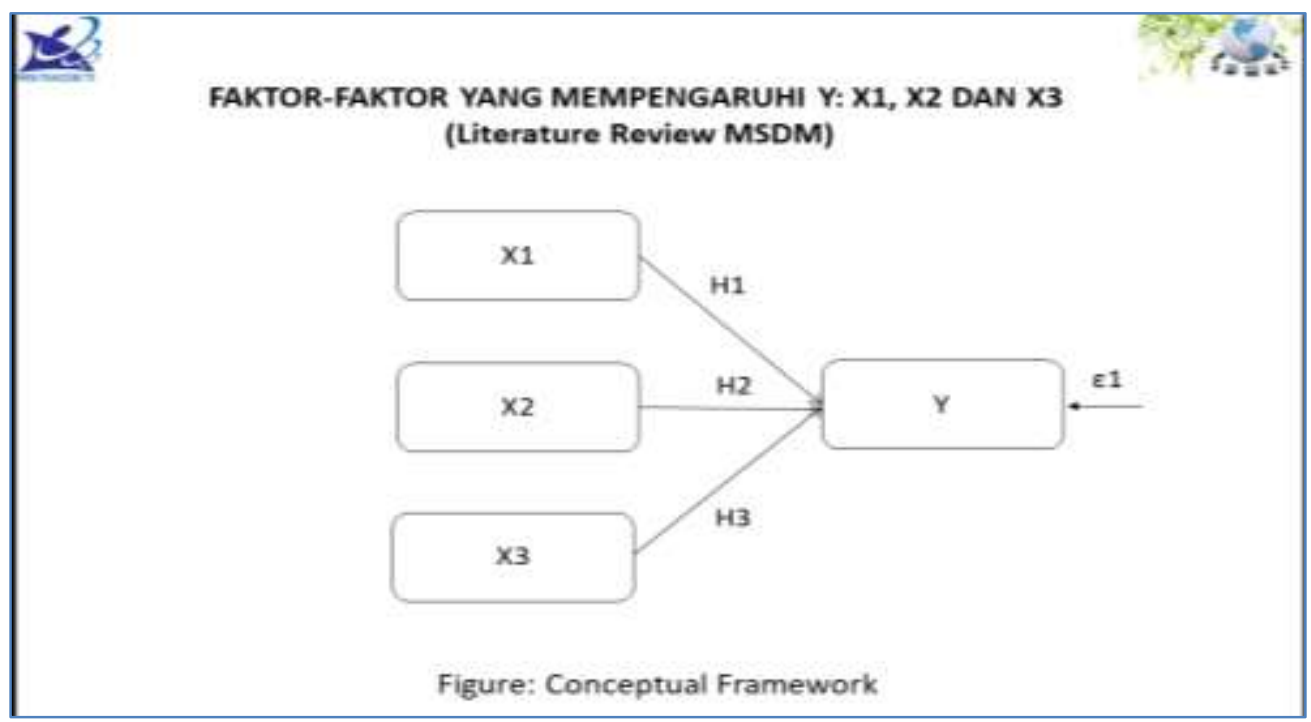

Figure 1: Conceptual Framework 
Berdasarkan Kajian teori dan review hasil dari artikel yang relevan serta gambar dari conceptual framework, maka: Sistem Pendidikan(X1), Pengelolaan Pendidikan (X2), dan Tenaga Pendidi (X3) berpengaruh terhadap Manajemen Pendidikan Islam (Y)

Artikel ini membahas faktor-faktor mempengaruhi Manajemen Pendidikan Islam, yaitu Sistem Pendidikan, Pengelolaan Pendidikan dan Tenaga Pendidik. Selain Dari 3 faktor ini yang mempengaruhi mekanisme berpikir kesistemik dalam pendidikan islam, masih banyak faktor lain lagi berdasar riset sebelmnya di antaranya adalah: 1) Sistem Informasi: (Sari \& Ali, 2019), (Shobirin \& Hapzi Ali, 2019), (Ashshidiqy \& Ali, 2019), (Djojo \& Ali, 2012), (Desfiandi, Desfiandi, et al., 2017); 2) Organisasi:(Sari \& Ali, 2019), (Brata, Husani, Hapzi, 2017), (Limakrisna et al., 2016), (Desfiandi, Fionita, et al., 2017), (Harini et al., 2020), (Riyanto, Pratomo, et al., 2017), (Sulaeman et al., 2019), (Ali, 1926), (Masydzulhak et al., 2016), (Widodo et al., 2017), (Silitonga et al., 2017), (Rivai et al., 2017), (Prayetno \& Ali, 2017); 3) Pelaksanaan: (Rachman \& Ali, 2016), (Ansori \& Ali, 2017), (Rachman \& Ali, 2016), (Sulaeman et al., 2019), (No et al., 2017), (Agussalim et al., 2020); 4) Kepemimpinan:(Limakrisna et al., 2016), (Bastari et al., 2020), (Anwar et al., 2020), (Ali et al., 2016), (Djoko Setyo Widodo, P. Eddy Sanusi Silitonga, 2017), (Chauhan et al., 2019), (Elmi et al., 2016). 5) Lingkungan: (Mulyani et al., 2020), (Ali \& Sardjijo, 2017), (Riyanto, Sutrisno, et al., 2017)

\section{KESIMPULAN DAN SARAN}

\section{Kesimpulan}

Berdasarkan rumusan artikel dan pembahasan maka dapat di di rumuskan hipotesis untuk riset selanjutnya:

1. Sistem Pendidikan berpengaruh terhadap Manajemen Pendidikan Islam

2. Pengelolaan Pendidikan berpengaruh terhadap Manajemen Pendidikan Islam

3. Tenaga Pendidik berpengaruh terhadap Manajemen Pendidikan Islam

\section{Saran}

Bersdasarkan Kesimpulan di atas, maka saran pada artikel ini adalah bahwa masih banyak factor lain yang mempengaruhi Manajemen Pendidikan Islam, selain dari Sistem Pendidikan, Pengelolaan Pendidikan, dan Tenaga Pendidik pada semua tipe dan level organisasi atau Pendidikan, oleh karena itu masih di perlukan kajian yang lebih lanjut untuk mencari faktor-faktor lain apa saja yang dapat memepengaruhi Manajemen Pendidikan Islam selain yang varibel yang di teliti pada arikel ini.

\section{DAFTAR RUJUKAN}

Agussalim, M., Ndraha, H. E. M., \& Ali, H. (2020). The implementation quality of corporate governance with corporate values: Earning quality, investment opportunity set, and ownership concentration analysis. Talent Development and Excellence.

Ahmad, H. (2017). Pengaruh Motivasi Belajar, Self Control dan Critical Thinking terhadap Prestasi Belajar Mahasiswa Prodi Pendidikan Ekonomi STKIP PGRI Situbondo. Jurnal Ekonomi Pendidikan Dan Kewirausahaan, 5(2), 263-274.

Ali, H. (1926). Evolution of Tank Cascade Studies of Sri Lanka. Saudi Journal of Humanities 
and Social Sciences. https://doi.org/10.21276/sjhss

Ali, H., Mukhtar, \& Sofwan. (2016). Work ethos and effectiveness of management transformative leadership boarding school in the Jambi Province. International Journal of Applied Business and Economic Research.

Ali, H., \& Sardjijo. (2017). Integrating Character Building into Mathematics and Science Courses in Elementary School. International Journal of Environmental and Science Education. https://doi.org/10.1007/s10648-016-9383-1

Ananda, R., \& Amiruddin, A. (2019). Perencanaan Pembelajaran.

Ansori, A., \& Ali, H. (2017). Analisis Pengaruh Kompetensi Dan Promosi Terhadap Kinerja Pegawai Negeri Sipil Pada Sekretariat Daerah Kabupaten Bungo. Jurnal Ilmiah Universitas Batanghari Jambi. https://doi.org/10.33087/jiubj.v15i1.198

Anwar, K., Muspawi, M., Sakdiyah, S. I., \& Ali, H. (2020). The effect of principal's leadership style on teachers' discipline. Talent Development and Excellence.

Ashshidiqy, N., \& Ali, H. (2019). PENYELARASAN TEKNOLOGI INFORMASIDENGAN STRATEGI BISNIS. Jurnal Ekonomi Manajemen Sistem Informasi. https://doi.org/10.31933/jemsi.v1i1.46

Asrifan, A. (2021). APLIKASI DAN IMPLIKASI BERPIKIR SISTEMIK (SYSTEMIC THINKING) DALAM KEHIDUPAN.

Bastari, A., -, H., \& Ali, H. (2020). DETERMINANT SERVICE PERFORMANCE THROUGH MOTIVATION ANALYSIS AND TRANSFORMATIONAL LEADERSHIP. International Journal of Psychosocial Rehabilitation. https://doi.org/10.37200/ijpr/v24i4/pr201108

Brata, Husani, Hapzi, B. H. S. A. (2017). Saudi Journal of Business and Management Studies Competitive Intelligence and Knowledge Management: An Analysis of the Literature. Saudi Journal of Business and Management Studies. https://doi.org/10.21276/sjbms

Chauhan, R., Ali, H., \& Munawar, N. A. (2019). BUILDING PERFORMANCE SERVICE THROUGH TRANSFORMATIONAL LEADERSHIP ANALYSIS, WORK STRESS AND WORK MOTIVATION (EMPIRICAL CASE STUDY IN STATIONERY DISTRIBUTOR COMPANIES). Dinasti International Journal of Education Management And Social Science. https://doi.org/10.31933/dijemss.v1i1.42

Desfiandi, A., Desfiandi, A., \& Ali, H. (2017). Composite Stock Price Index (IHSG) Macro Factor in Investment in Stock (Equity Funds). International Journal of Economics and Financial Issues.

Desfiandi, A., Fionita, I., \& Ali, H. (2017). Implementation of the information systems and the creative economy for the competitive advantages on tourism in the province of Lampung. International Journal of Economic Research.

Djojo, A., \& Ali, H. (2012). Information technology service performance and client's relationship to increase banking image and its influence on deposits customer banks loyalty (A survey of Banking in Jambi). In Archives Des Sciences.

Djoko Setyo Widodo, P. Eddy Sanusi Silitonga, \& H. A. (2017). Organizational Performance: Analysis of Transformational Leadership Style and Organizational Learning. Saudi Journal of Humanities and Social Sciences. https://doi.org/10.21276/sjhss.2017.2.3.9

Djunaidi, A. (2020). Proses berpikir sistemik mahasiswa dalam memecahkan masalah 
pengambilan keputusan. Universitas Negeri Malang.

Dolong, M. J. (2016). Sudut pandang perencanaan dalam pengembangan pembelajaran. Inspiratif Pendidikan, 5(1), 65-76.

Elmi, F., Setyadi, A., Regiana, L., \& Ali, H. (2016). Effect of leadership style, organizational culture and emotional intelligence to learning organization: On the Human Resources Development Agency of Law and Human Rights, Ministry of Law and Human Rights. International Journal of Economic Research.

Fahrurazi, F., \& Rosadi, K. I. (2021). FAKTOR YANG MEMPENGARUHI MODEL SISTEM PENDIDIKAN ISLAM: JENIS KESISTEMAN, KONSTRUKSI KESISTEMAN, BERPIKIR KESISTEMAN. JURNAL MANAJEMEN PENDIDIKAN DAN ILMU SOSIAL, 2(1), 18-30.

Hanifah, A. N., Mirna, M., Mulianty, H. R., \& Fitriani, N. (2018). HUBUNGAN ANTARA KEMAMPUAN BERPIKIR KRITIS MATEMATIS DENGAN HABITS OF MIND SISWA SMK YANG MENGGUNAKAN PENDEKATAN MODEL ELICITING ACTIVITIES (MEAs). JPMI (Jurnal Pembelajaran Matematika Inovatif), 1(1), 29-36.

Harini, S., Hamidah, Luddin, M. R., \& Ali, H. (2020). Analysis supply chain management factors of lecturer's turnover phenomenon. International Journal of Supply Chain Management.

Iryani, E., Ali, H., \& Rosyadi, K. I. (2021). BERFIKIR KESISTEMAN DALAM SOCIAL SUPPORT: TA'AWUN UPAYA PENINGKATAN MUTU PENDIDIKAN AGAMA ISLAM DI MAS AL-IHSANIYAH SARANG BURUNG MUARO JAMBI. JURNAL MANAJEMEN PENDIDIKAN DAN ILMU SOSIAL, 2(1), 413-425.

Limakrisna, N., Noor, Z. Z., \& Ali, H. (2016). Model of employee performance: The empirical study at civil servants in government of west java province. International Journal of Economic Research.

Masydzulhak, P. D., Ali, P. D. H., \& Anggraeni, L. D. (2016). The Influence of work Motivationand Job Satisfaction on Employee Performance and Organizational Commitment Satisfaction as an Intervening Variable in PT. Asian Isuzu Casting Center. In Journal of Research in Business and Management.

Mulyani, S. R., Ridwan, M., \& Ali, H. (2020). Model of human services and resources: The improvement efforts of Silungkang restaurant attractiveness on consumers. Talent Development and Excellence.

Mushafak, I. (2015). Sistem Kontrol Pendidikan Karakter di Sekolah dan Keluarga. Ta'allum: Jurnal Pendidikan Islam, 3(1), 77-91.

No, P., Sanusi, A., Desfiandi, A., Ali, H., St, A. B., \& Ct, R. A. (2017). PERFORMANCEBASED ON THE HIGHER EDUCATION QUALITY IN PRIVATE COLLEGES. Proeeding MICIMA.

Prayetno, S., \& Ali, H. (2017). Analysis of advocates organizational commitment and advocates work motivation to advocates performance and its impact on performance advocates office. International Journal of Economic Research.

Priansa, D. J. (2014). Perencanaan \& Pemgembangan SDM.

Priyatna, M. (2017). Manajemen pengembangan sdm pada lembaga pendidikan Islam. Edukasi Islami: Jurnal Pendidikan Islam, 5(09), 21.

Rachman, S. M. A., \& Ali, H. (2016). Divorce without in-between: An empirical study on the 
failure of mediation in the religious court of sengeti jambi province. Man in India.

Rivai, A., Suharto, \& Ali, H. (2017). Organizational performance analysis: Loyalty predictors are mediated by work motivation at urban village in Bekasi City. International Journal of Economic Research.

Riyanto, S., Pratomo, A., \& Ali, H. (2017). EFFECT OF COMPENSATION AND JOB INSECURITY ON EMPLOYEE ENGAGEMENT (STUDY ON EMPLOYEE OF BUSINESS COMPETITION SUPERVISORY COMMISSION SECRETARIAT). International Journal of Advanced Research. https://doi.org/10.21474/ijar01/4139

Riyanto, S., Sutrisno, A., \& Ali, H. (2017). International Review of Management and Marketing The Impact of Working Motivation and Working Environment on Employees Performance in Indonesia Stock Exchange. International Review of Management and Marketing.

Sari, V. N., \& Ali, H. (2019). PERUMUSAN STRATEGI BAGI UNIVERSITAS PUTRA INDONESIA YPTK PADANG UNTUK MERAIH KEUNGGULAN BERSAING. Jurnal Ekonomi Manajemen Sistem Informasi. https://doi.org/10.31933/jemsi.v1i1.42

Shobirin, M., \& Hapzi Ali. (2019). STRATEGI PENGEMBANGAN INFRASTRUKTUR DALAM MENINGKATKAN PELAYANAN PENUMPANG DI BANDAR UDARA INTERNASIONAL SOEKARNO HATTA CENGKARENG. Jurnal Ekonomi Manajemen Sistem Informasi. https://doi.org/10.31933/jemsi.v1i2.66

Silitonga, P. E. S., Widodo, D. S., \& Ali, H. (2017). Analysis of the effect of organizational commitment on organizational performance in mediation of job satisfaction (Study on Bekasi City Government). International Journal of Economic Research.

Somantri, M. (2014). Perencanaan pendidikan. PT Penerbit IPB Press.

Sulaeman, A. S., Waluyo, B., \& Ali, H. (2019). Making dual procurement and supply chain operations: Cases in the indonesian higher education. International Journal of Supply Chain Management.

Susanti, A. T., Prayitno, B. A., \& Sudarisman, S. (2015). Pengaruh Model Problem Based Learning disertai Media Key Relation Chart Terhadap Kemampuan Berpikir Kritis dan Kerjasama Siswa dalam Kelompok pada Kelas VIII SMP Negeri 14 Surakarta Tahun Pelajaran 2012/2013. Jurnal Pendidikan Biologi, 7(41), 1-13.

Tabrani, Z. A. (2013). Modernisasi Pengembangan Pendidikan Islam (Suatu Telaah Epistemologi Pendidikan). Serambi Tarbawi, l(1).

Tinggi, S., Islam, A., \& Madiun, S. (n.d.). ( MSDM ) PADA LEMBAGA PENDIDIKAN.

Umam, M. K. (2020). Dinamisasi Manajemen Mutu Persfektif Pendidikan Islam. Al-Hikmah: Jurnal Kependidikan Dan Syariah, 8(1), 61-74.

Widodo, D. S., Silitonga, P. E. S., \& Ali, H. (2017). Analysis of organizational performance: Predictors of transformational leadership style, services leadership style and organizational learning: Studies in Jakarta government. International Journal of Economic Research. 